This is the version of the article accepted for publication in Water Resources Management published by Springer online 17 September 2016. Final version available at: http://dx.doi.org/10.1007/s11269-016-1496-2 Accepted version downloaded from SOAS Research Online: http://eprints.soas.ac.uk/22868/

\title{
Regulatory Constructivism: Application of Q Methodology in Italy and China
}

\author{
Eduardo Araral (National University of Singapore) \\ Alberto Asquer (SOAS, University of London) \\ Yahua Wang (Tsinghua University)
}

Revised $16^{\text {th }}$ May 2016, $26^{\text {th }}$ August 2016

\begin{abstract}
Conventional view holds that beliefs play an important role in the development of regulations but there is little evidence to support this claim. We use Comparative Q Methodology to systematically map out and compare the beliefs of public officers in China and Italy, two countries with contrasting sets of institutions but have both adopted similar ideas about integrated water resource management. We find some similarities and differences in the beliefs of public officers in both countries. In particular, we find that in both countries beliefs on the regulation of water utilities are diverse and fragmented on issues such as ownership structure of water utilities, how water infrastructure development should be funded, and how tariffs should be regulated. Our findings have two implications for theory, methods and practice. First, the Q methodology is a useful tool for systematically mapping out the beliefs of regulators and managers. Second, systematically mapping out beliefs will help facilitate the development of an alternative regime of regulation such as negotiated rule making. This alternative regime can provide substantial benefits such as more efficient rule making, more cost effective enforcement and compliance, and more equitable in terms of balancing the interests of stakeholders.
\end{abstract}

Keywords: Water utilities; water services; negotiated rule making; water regulation; ideas; discourse; subjectivity; Q Methodology; Italy; China 
This is the version of the article accepted for publication in Water Resources Management published by Springer online 17 September 2016. Final version available at: http://dx.doi.org/10.1007/s11269-016-1496-2 Accepted version downloaded from SOAS Research Online: http://eprints.soas.ac.uk/22868/

\section{Introduction}

Beliefs play an important - albeit often neglected - role in the management and regulation of water utilities. For example, ideas on neo-liberal beliefs on water regulation that especially spread in the 1970's and 1980's resulted in widespread privatization and re-regulation of water utilities in many countries and regions in the world (Thatcher 1998, 2002). The natural monopoly characteristics of urban water supply has led to calls for water concessions to be subjected to regulation. Problems of water scarcity and the need for more efficient water management has led to calls for an integrated approach to water management. Water is a local public good and therefore is subject to local politics and beliefs. Water being essential to life has led to calls for the State to guarantee it as a basic human right and as such should not be left in the hands of the private sector.

While there are no disagreements in the literature on the importance of beliefs and ideas in the design and enforcement of regulations, little has been done to more systematically study beliefs and ideas and how they matter. For example, there are divergent views on how water utilities are to be owned and regulated - ranging from pure public ownership on one hand to complete privatization on the other hand and some form of regulation in between.

In Europe, there are wide ranging debates on a number of issues. For instance, how should water tariffs and other service conditions be set? How should water infrastructure development be financed (Guerrini et al. 2011; Marques and Berg 2011; Massarutto 2007; Romano et al. 2013)? What is the role of regulators, their degree of autonomy and the scope for negotiated rule making? It is understandable that European countries would have divergent views on water utilities regulation given their different legal traditions, political ideologies, beliefs about the market and state, among others. Similarly, in China, we find widely divergent views among local officials about ownership and regulation of water utilities in the context of diverse geographical, economic and social conditions in various provinces as a country with a vast territory and huge population. 
This is the version of the article accepted for publication in Water Resources Management published by Springer: http://link.springer.com/journal/volumesAndlssues/11269

Accepted version downloaded from SOAS Research Online: http://eprints.soas.ac.uk/22868/

What these two anecdotal examples from China and Europe suggests is that there is a need to more systematically map out and study how beliefs matter to the ownership, regulation and management of water utilities in particular and to regulation in general. Systematically mapping out beliefs will help facilitate the development of an alternative regime of regulation - negotiated rule making - which can provide substantial benefits to many developing countries in the form of more efficient rule making, more cost effective in terms of enforcement and compliance, more equitable in terms of balancing the interests of stakeholders and other benefits.

In this paper, we introduce the use of the Comparative Q Methodology to systematically map out, compare and study the beliefs of public officers using data from water utilities in China and Italy. First, we want to investigate whether local public officers share any 'hegemonic' view of water service provision or rather they hold conflicting perspectives. Second, we want to know whether these beliefs vary within a country and between countries with different political and institutional contexts. These questions are part of a bigger question on regulatory theory on whether regulations eventually converge or diverge.

The cohesiveness or fragmentation of beliefs on water utilities management are important because may have various repercussions on water service provision, including, for example, influence on the stability or change of present water regulatory regimes and water utilities management styles. The comparison between two different countries - namely, one from the European context, Italy, and one from a non-European context, China - also helps in understanding how ideas on water utilities management differ across institutional and cultural settings.

The rest of the paper is organized as follows. The next section will review the literature on the role of ideas in the regulation and management of water utilities. Section three will illustrate the methodology followed in the study. Section four will present the results from the 
This is the version of the article accepted for publication in Water Resources Management published by Springer: http://link.springer.com/journal/volumesAndlssues/11269

Accepted version downloaded from SOAS Research Online: http://eprints.soas.ac.uk/22868/

analysis and section five will discuss the findings. Finally, section six will draw the conclusions and indicate venues for further research.

\section{The role of beliefs and ideas in the regulation of water utilities}

Various fields of social sciences hold diverse understandings of the role of beliefs and ideas as drivers of social and economic phenomena. Within economics, beliefs and ideas play an important role as foundational components of rational agents. When it comes to explaining the economic regulation of utilities, however, we find that beliefs and ideas have relatively little explanatory role. Public interest theories of regulation posit that benign regulators know what the interests of the society as a whole are (Pigou 1932; Posner 1974; Ogus 1994). Private (or capture) theories of regulation build on the assumption that the regulated industry or particular firms seek to maximize their material net benefits (Stigler 1971; Becker 1983; Peltzman 1989). These theories do not account for where beliefs and ideas come from, how they can change over time, and how change of beliefs and ideas result in reconfiguration of regulatory systems. Beliefs and ideas are mere 'epiphenomena' with respect to the more fundamental drivers of choice based on material interests.

In part of political science, beliefs and ideas play a relatively minor role as causal sources of policy stability and change with respect to structural and 'configurational' explanations. Neoinstitutionalist approaches, for example, grant large explanatory power to the distribution of individual stakes, to the resources that actors can leverage on, and on the relationships within networks of actors (Béland 2005; Klijn and Koppenjan 2004; Peters 2011; Weaver and Rockman 1993; Schmidt 2010, 2011). Some authors, however, have acknowledged that also beliefs and ideas play an important role in the policy process, most notably Kingdon (1984) and Sabatier (1988; Sabatier and Jenkins-Smith 1999). Some consideration for the causal role of beliefs and ideas in public policy has also been paid by research works that highlighted the importance of argumentation (Majone 1989), discourse (Schmidt 2002, 2010, 2011), culture 
This is the version of the article accepted for publication in Water Resources Management published by Springer: http://link.springer.com/journal/volumesAndlssues/11269

Accepted version downloaded from SOAS Research Online: http://eprints.soas.ac.uk/22868/

(Lodge and Wegrich 2012), and legitimacy (Wang and Ching 2013) on public and regulatory policies.

We need to look at 'ideational' or 'constructivist' epistemological perspectives to social science in order to find a primary role granted to beliefs and ideas as explanatory sources of social phenomena. It should be noted, first, that the very concepts of beliefs and ideas are defined in different ways. Beliefs are generally understood as "mental constructions of experience, often condensed and integrated into schemata or concepts that are held to be true and that guide behavior" (Sigel 1985: 313) or "psychologically held understandings, premises, or propositions about the world that are felt to be true" (Richardson 1996: 103). Ideas have been variously illustrated, for example, as "theories, conceptual models, norms, world views, frames, principled beliefs, and the like" (Campbell 2002: 21), "claims about descriptions of the world, causal relationships, or the normative legitimacy of certain actions", (Parsons 2002: 48), focal points (Goldstein and Keohane 1993), strategic constructions (Jabko 2006), narratives (Roe 1994), frames of reference (Jobert 1989), collective memories (Rothstein 2005), and traditions (Katzenstein 1996). Some, like Campbell (2002) and Schmidt (2010), also drew distinctions between kinds of ideas, such as the one between cognitive and normative contents and the one between levels of generalizability (i.e., policies, programs, and philosophies).

It should be noted that also ideational or constructivist approaches to social sciences have made relatively little progress to explain how ideas matter in public policy and regulation (Yee 1996). Some authors highlighted that ideas form the cognitive basis of 'sentient' agents who reflect upon, debate about, and argue for preserving or changing existing institutional arrangements (Fisher and Gottweis 2013; Schmidt 2008, 2010). In this sense, ideas provide cognitive paradigms (that include taken-for-granted beliefs; Heilbroner and Milberg 1995) and shortcuts (that include heuristics to make sense and solve complex problem situations; Suchman 1997) to deal with policy issues. Ideas also make agents challenge existing 
This is the version of the article accepted for publication in Water Resources Management published by Springer: http://link.springer.com/journal/volumesAndlssues/11269

Accepted version downloaded from SOAS Research Online: http://eprints.soas.ac.uk/22868/

institutions and related patterns of distribution of resources (Béland 2009; Blyth 2001), although sometimes they restrict the scope of policy options under consideration (Campbell 2002). Finally, ideas also help providing rationales for decisions that help justify actions and persuade others of the merits of policy options (Béland 2005).

These general considerations on the role of beliefs and ideas in social science are relevant to the study of regulation of water utilities. Ideas on how water services should be provided play an important role in orienting the decisions of policy-makers. At the local level, public officers (that we understand here as members of the policy community that includes both elected public officers as well as appointed or career regulators and managers of public utilities) enjoy some discretion in the design of regulatory institutions for the delivery of water supply and sanitation services. In France, for example, municipalities can decide whether to contract out the provision of water services to business firms selected through tender offer competitions or to retain the management of water services within municipal departments. Which regulatory system is selected, and whether it is maintained over time or substituted with another one, also depends on the role of ideas about the relative merit of alternative policy options. For example on some occasions, like the 'remunicipalisation' of water service provision in Grenoble in 2001 and in Paris in 2010, ideas make policy-makers contemplate the possibility of regulatory policy reversals in conditions of seemingly stable institutional arrangements.

Ideas on the regulation of water utilities include that water service provision should be subjected to economic regulation, especially because of natural monopoly features of water infrastructure. This idea is articulated in the shared view, within water policy circles, that economies of scale result in advantages for larger operators, that network economies produce benefits for the operators of larger infrastructure networks, and that durable and immobile assets discourage entry from potential competitors (Araral 2008, 2009, 2013; Gómez Ibáňez 2003; Estache and Martimort 1999; Laffont and Tirole 1993; Spulberg and Sabbaghi 1994). 
Relatively less consensus exists, however, on how precisely water utilities should be regulated. Ideas include regulating water utilities through independent regulatory authorities (IRAs, such as OFWAT in England and Wales), or through franchise contracts (as it is often done in France), or through the retention of water services under full public ownership and control (as it is often the case in Germany and Italy) or under semi-privatized water utilities (i.e., mixed public-private ownership firms or 'institutional public-private partnerships') (Araral and Wang 2013; Ballance and Taylor 2005; Rouse 2007). Ideas also include various arrangements regarding the efficiency of water firms, the pursuit of equity values, the conditions for the financial self-sufficiency of water services, and the relationships between the regulators and the regulated firms.

Although beliefs and ideas can be granted, in principle, an important role to explain regulatory policies, little empirical research exists on what public officers think about water utilities regulation. In part, this lack of research may originate from the methodological and operational difficulties to access the subjective understandings of individuals. Yet, the ideational sphere of public officers on the regulation of water utilities provides an indication of the issues that public officers care about, of the different options that they consider available to them, and of their normative stance towards alternative ways of regulating water services. The ideational sphere of public officers can also contain an anticipation (or 'seeds', in a metaphorical sense) of policy ideas that could gain traction in the policy arena at later stage, when appropriate windows of opportunity for policy change occur (Kingdon, 1984).

An investigation of the beliefs and ideas on water regulation seems important in order to appreciate whether public officers hold a variety of views on water regulation or tend to adopt a more shared and uniform perspective towards regulatory options. Such an investigation is needed if we want to better understand the similarities and differences of the water regulatory discourse across different countries and institutional contexts. In addition, systematically mapping out beliefs will help facilitate the development of an alternative 
This is the version of the article accepted for publication in Water Resources Management published by Springer: http://link.springer.com/journal/volumesAndlssues/11269

Accepted version downloaded from SOAS Research Online: http://eprints.soas.ac.uk/22868/

regime of regulation such as negotiated rule making. Negotiated rule making is a kind of rule making process that includes a negotiation between parties affected by a regulation before the issue of a proposed regulation (Coglianese 1997). Negotiated rule making can provide substantial benefits such as more efficient rule making, more cost effective enforcement and compliance, and more equitable in terms of balancing the interests of stakeholders. When applied to water regulation, this alternative regime entails that greater openness about each party's positions and preferences helps exploring the room for mutually advantageous regulations and prevent conflicts that might arise.

\section{Research design}

This study aims to investigate what are the beliefs and ideas held by public officers on the regulation of water utilities. The investigation is intended to describe whether public officers share a 'hegemonic' view of water service regulation or they hold conflicting viewpoints on this subject. Answering this research question requires to open up the 'black box' of public officers' understanding of water regulatory regimes. Beliefs and ideas have been typically accessed through qualitative research methods (Schmidt 2011). There are obviously some merits in collecting and analyzing interviews or other qualitative evidence because they enable researchers to appreciate the emic perspective of participants to a policy domain. However, there are also some limitations to qualitative research because this method fails to provide a systematic evidence of what ideas individuals hold, how different or similar ideas are between individuals, and how much ideas are shared among the participants of a policy domain. We know that some ideas typically play a dominant or hegemonic role within a policy arena (Jobert 1989) while other ideas are confined to the background or to the margins of the policy discourse (at least, in the public one). If beliefs and ideas matter in the regulation of water utilities, we need to resort to enriched methodological tools for gathering and analyzing them. 
This is the version of the article accepted for publication in Water Resources Management published by Springer: http://link.springer.com/journal/volumesAndlssues/11269

Accepted version downloaded from SOAS Research Online: http://eprints.soas.ac.uk/22868/

This study employs Q Methodology for accessing and analyzing ideas on the regulation of water utilities. Q Methodology is a statistical technique that helps identify the patterns of subjective perspectives held by a group of individuals (Stephenson 1953; Brown 1980). Different from other forms of quantitative research, Q Methodology is not intended to test hypothesized causal relationships but to identify 'bundles' of ideas (in the form of statements) shared between individuals. Likewise, Q Methodology differs from various forms of qualitative research in that it employs statistical correlations for inferring associations between ideas (in the form of statements) rather than exclusively relying on researchers' interpretation. Interpretation, however, is required to make sense of the results of the analysis, especially because ideas need to be understood within the context of policy domain-specific political discourses.

In order to better appreciate the variety of ideas on water regulation that are present within domestic political discourses, this study employs - more precisely - a Comparative Q Methodology approach. The analysis of the beliefs and ideas held by public officers has to be comparative in nature. It is by contrasting and comparing beliefs and ideas between countries with different political and institutional contexts that we can draw inferences about the origins of such beliefs and ideas and their tendencies to change over time. The present study, then, consists of a comparative analysis of beliefs and ideas on water regulation that are held by public officers in two different countries (namely, Italy and China), whose argument for selection is illustrated below. The analysis, in this respect, is functional to start addressing more general questions about regulatory theory on whether regulations eventually converge or diverge.

The study was conducted by identifying, first, a series of statements (called Q sample) that represents that variety of views around the issue at stake (so-called 'concourse') (Dryzek and Berejikian 1993; Dryzek and Holmes 2002; Steelman and Maguire 1995). The Q sample employed in this study was constructed in a previous research (Asquer, 2014) on the basis of 
This is the version of the article accepted for publication in Water Resources Management published by Springer: http://link.springer.com/journal/volumesAndlssues/11269

Accepted version downloaded from SOAS Research Online: http://eprints.soas.ac.uk/22868/

a selection of about 150 statements drawn from documentary sources and 20 interviews conducted in prior studies (Asquer 2010, 2011). The Q sample, shown in Table 1, consisted of 30 statements that describe (a) the normative stance towards values that should be protected in the regulation of water utilities; (b) the general regulatory design principles that should be followed; (c) initial conditions that characterize the present state of affairs in the local water industry; (d) process conditions that relate to features of the regulatory process; and (e) context conditions that relate to environmental circumstances. Admittedly, the limited number of sentences of the Q sample prevents us from gaining a more detailed and nuanced account of the variety of views on the regulation of water utilities. On the other hand, the size of the Q sample is constrained by practical considerations for the amount of time and effort that participants are willing to spend in the data collection stage. Admittedly the definition of the $\mathrm{Q}$ sample on the basis of evidence collected from the regulatory discourse in one particular country (Italy) raises some concerns about the possibility to map out beliefs and ideas on water regulation in another country (China). On the other hand, the Q sample was originally designed also taking into account theoretical arguments about fundamental regulatory issues that arise irrespective from any particular institutional and political context. The second stage of Comparative Q Methodology consisted of the purposive selection of participants (called P sample) that were invited to express their degree of agreement with the sentences of the Q sample. This study included two P samples, one made of 24 respondents in Italy and the other of 68 participants in China. The selection of the two countries is based on theoretical and empirical considerations. First, drawing the comparison between relatively distant institutional and political contexts helps distinguishing beliefs and ideas that are shared in the water sector irrespective of particular country conditions form those that are related to particular features of the context. In this respect, Italy and China exhibit some remarkable differences. During the past three decades, China experienced a gradual and managed transition from centralized planned economy to a market-oriented economy 
(MacMillan and Naughton 1992; Qian and Weingast 1996). The institutional and political context for water regulation, however, remains largely dependent on an extended hierarchy that includes the Ministry of Water Resources, the Ministry of Environmental Protection, and several agencies like the Water Resources Bureaus (WRBs) that operate at the provincial, prefectural, and country levels and the River Basin Conservation Commissions for China's main river basins (Qiu and Li, 2008). And the idea of adopting market to allocate water resources was spread since 2000 and was accepted by public officers in recent years. Although immature water rights market is emerging (Wang, 2012), the water sector is still mainly under the regulation of government and the water rights market is still in its infancy. Water regulation in Italy, in contrast, followed an erratic trajectory since 1994 - when a reform dismantled a regime of widespread public sector ownership and control of water utilities - and during the 2000's - when various policy measures aimed to stimulate greater involvement of private business and capital into the sector (Asquer 2010, 2011, 2014; Massarutto et al 2008; Romano and Guerrini 2011). Political support for the privatization of water utilities dissolved over time, however. In 2011, a referendum resulted in the abrogation of legislative provisions about the tender out of water concessions and the inclusion of a return to investment in water tariff.

Italy and China also share, however, some common threads in the public discourse on water regulation. During the last decades, both Italy and China became increasingly exposed to neo-liberal ideas that conflicted with principles of public sector ownership and control of water services. In Italy, the public discourse polarized around the views that water should be privatized because of public sector inefficiencies and those that opposed privatization because of equity and environmental concerns (Massarutto and Ermano, 2013). In China, ideas about water regulation came to include a greater role for private financing, together with greater consideration of issues related to rapid urbanization, industrialization, growing agricultural demand, environmental degradation, and climate change threats ( $\mathrm{Hu}$ and Wang 
This is the version of the article accepted for publication in Water Resources Management published by Springer: http://link.springer.com/journal/volumesAndlssues/11269

Accepted version downloaded from SOAS Research Online: http://eprints.soas.ac.uk/22868/

2000; Zhang et al. 2009). In both countries, also, ideas on water resource management have incorporated the principles of integrated river basin management.

The selection of the participants to the $\mathrm{P}$ sample is also based on theoretical and empirical considerations. In Q Methodology, participants should provide alternative perspectives on the issue at stake. It would be necessary to have ex ante knowledge of individuals' viewpoints in order to select participants appropriately, but typically it helps to sample individuals who hold different positions within the particular social or policy domain of interest. Participants to the P sample in Italy were selected among public officers in local governments, namely members of municipal assemblies and managers of local government-owned water firms from 19 cities. The average (and median) age of the 24 respondents was 45 year old. The respondents included 21 male and 3 female. The average (and median) work experience in the water sector of the respondents was 5 years (the sample included respondents with work experiences raging from 1 to 20 years). Half of respondents declared themselves as having political orientation towards 'leftist' parties ( $50 \%$ of the sample), while others were oriented towards 'centre' (12.5\%) and 'right' parties (20.8\%). Only 4 respondents did not report any political orientation. Participants to the $\mathrm{P}$ sample in China included public officers in charge or related to water firms including waterworks or construction bureau or water conservancy bureau of the provincial, municipal and county level. While data from the Italian sample were collected online following individual emails to public officers in various cities across the country, those from the Chinese sample were collected in part during training sessions organised in Beijing and Hangzhou by the Ministry of Water Resources and in part by sending the questionnaire to specific provinces (Guangxi, Sichuan, Shannxi and Xinjiang). Respondents of the Chinese sample were 35 year old an average (mean and median) and had 11.5 year work experience (mean and median). $80 \%$ of respondents were male and $20 \%$ female. As the political spectrum that was used for asking the Italian sample about their political orientation would be meaningless in the China context, respondents were asked to 
This is the version of the article accepted for publication in Water Resources Management published by Springer: http://link.springer.com/journal/volumesAndlssues/11269

Accepted version downloaded from SOAS Research Online: http://eprints.soas.ac.uk/22868/

express their policy orientation towards the attitude that the government should take towards water markets. Respondents largely agreed that the government should take a strongly strict attitude towards water markets $(52.94 \%)$ or a strict one $(38.24 \%)$. A minority agreed with a moderate $(7.35 \%)$ or a loose attitude $(1.47 \%)$.

In the third stage of Q Methodology, participants were invited to sort the statements of the Q sample into a 'grid' shaped as a normal distribution (i.e., a pyramid made of 'slots' arranged along a scale ranging from the sentence that any participant agrees the least with, valued -5 , to the sentence that any participant agrees the most with, valued +5 ). Sorting was done online through FlashQ software (Braehler and Hackert 2013). The grid is intended to make participants rank the order in which they agree with the sentences, rather than merely expressing the extent to which they agree with them or not (as it is done in questionnaire surveys). Finally, the responses (called Q sorts) are analyzed through a by-person factor analysis (Stephenson 1953) to reveal correlated groups of statement preferences. Analysis was conducted with PQMethod software (Schmolck 2013). The factors that result from the analysis can be understood as groups of claims that are related to particular views on the regulation and management of water utilities.

\section{Results from the analysis}

Results from the analysis of the data are presented in Tables 2 to 9. The analysis conducted in both countries resulted in the identification of five factors. Tables 2 and 3 exhibit the factor matrix with defining sorts from the data collected in Italy and China, respectively. These tables indicate (in bold) those respondents whose Q sorts contribute defining each particular factor. Tables 4 and 5 illustrate factor Q sort values for each statement. These tables indicate the rank value that each sentence of the Q sample is given in each particular factor. Tables 6 and 7 show the correlations between factors. In the analysis conducted in both countries, some factors are moderately correlated with each other (e.g., factors 1 and 2 in Italy, 
This is the version of the article accepted for publication in Water Resources Management published by Springer: http://link.springer.com/journal/volumesAndlssues/11269

Accepted version downloaded from SOAS Research Online: http://eprints.soas.ac.uk/22868/

correlation 0.4999, and factors 1 and 2 in China, correlation 0.3910). Finally, Tables 8 and 9 present the defining statements for each factor. These tables display what are the sentences that each factor - i.e., 'view' on the topic - mostly agrees and disagrees with. The results presented in Tables 8 and 9, therefore, are those offered to the interpretation for understanding what local public officers in Italy and in China think of the regulation and management of water utilities.

The results of the analysis show that in both Italy and China local public officers hold a diverse and fragmented view on the regulation and management of water utilities. In Italy, we distinguish five factors in relation to different views on water regulation. Factor 1 can be conveniently labeled as a "public sector interventionist" view of regulation and management of water utilities. This view is characterized by stronger agreement with claims such as "Local water services should be provided by full public ownership firms" (statement 30), while it includes rejection for sentences like "Local water services should be provided by business firms subjected to the pressure of market competition only" (statement 25). Factor 2 can be described as a "pessimistic" view on water utilities regulation. This view includes agreement, for example, with sentences like "Local public authorities tend to interfere in the management of water firms rather than supervising and regulating their conduct" (statement 19) and disagreement with claims like "Water firms are provided incentives to operate efficiently" (statement 24). Factor 3 can be understood as a "pragmatist" approach because the view agrees with statements like "Water tariffs should cover full cost, including a fair return to capital invested" (statement 3) although it disagrees with claims like local water services should be provided by business firms (either subjected to a regulatory agency or to the terms and conditions of franchise contracts; statements 26 and 27). Factor 4, instead, refers to the view of a "users protector", who agrees that water services should be managed according to principles of solidarity and protection of most vulnerable tariffs (statement 2), that water tariff should be kept under the control of public authorities to ensure affordability 
This is the version of the article accepted for publication in Water Resources Management published by Springer: http://link.springer.com/journal/volumesAndlssues/11269

Accepted version downloaded from SOAS Research Online: http://eprints.soas.ac.uk/22868/

(statement 4), and that local public authorities do not adequately monitor service quality (statement 10). Finally, Factor 5 illustrates the view of a "fatalist privatizer" that agrees that "water services provide an attractive opportunity for private investors" (statement 21) and that local water services should be provided by business firms subjected to the discretion of a regulatory agency (statement 26) or by mixed public-private ownership firms (statement 28). Also in China, each of the five factors is characterized by peculiar traits. Factor 1 is illustrative of a "strongly pro-public" view of water services regulation and management. The factor includes agreement with sentences that "water infrastructure development should be primarily financed by public funds" (statement 6), that "the water sector contains too few firms to stimulate any form of competition" (statement 14), and that "the attainment of profit bears negative effects on the quality of water services" (statement 15), and disagreement with the claim that "water infrastructure development should be primarily financed by user charges" (statement 5). Factor 2 can be understood to a "financially conscious" view of water service provision, instead: the view includes agreement with the claim that "water infrastructure development should be primarily financed by public funds "(statement 6), but also that "water tariffs should cover full cost, including a fair return to capital invested" (statement 3) and that "water tariffs should be kept under the control of public authorities to ensure affordability" (statement 4). Factor 3 illustrates a "business oriented" view that agrees that "water services should be managed according to business principles akin to those of forprofit firms" (statement 1) and that "water tariffs should cover full cost, including a fair return to capital invested" (statement 3), while the view disagrees on regulating water utilities through any means but franchises (disagreement with statements 28, 26 and 30). The view related to Factor 4 is a "public sector critic", because - although the view includes agreement that "the attainment of profit bears negative effects on the quality of water services" (statement 15) - it also agrees with claims that "local public authorities do not possess adequate knowledge, competences, and capabilities to regulate the conduct of water firms" 
(statement 13) and that they "do not adequately monitor service quality" (statement 10). Finally, Factor 5 relates to the view of a "private sector critic" who agrees on the claim that "water tariffs should cover full cost, including a fair return to capital invested" (statement 3), but also that market forces are ineffective in the water sector because of a lack of "reliable and comparable measures to assess the quality of services" (statement 16), of an adequate number of "firms to stimulate any form of competition" (statement 14), of ways to "compare the quality of the services with those provided by other water firms" (statement 22), and of "any serious threat of new entrants into the industry" (statement 20).

In comparative perspective, the results from the analysis show that the public discourse on water regulation in Italy and China includes some remarkable similarities and differences. From a normative perspective (statements 1-6), both the Italian and Chinese discourses exhibit an agreement (to a greater or lesser extent) with "Water services should be managed according to principles of solidarity and of protection of the most vulnerable users" (statement 2) and "Water tariffs should be kept under the control of public authorities to ensure affordability" (statement 4) across all the five views identified in the respective country analysis. The Italian discourse, however, includes some divergence across different views that are not present in the Chinese discourse. For example, statement 5 "Water infrastructure development should be primarily financed by users charges" is relatively controversial in Italy because it is supported by view of Factors 3 and 4 but it is strongly opposed by the view of Factor 2, while it is relatively consistent in China, where it is opposed (to a greater or lesser extent) by the views related to all the five factors. While these results can be partially understood in relation to a shared sense of public service role of water provision, they also convey the impression of some resistance towards user charges financing in China despite recent moves towards introduction of public-private partnerships (PPPs) as forms of private sector funding of water infrastructure. 
Also with respect to process conditions (statements 7-12), it is possible to identify some commonalities in the discourses on water regulation in Italy and China. In both the Italian and Chinese discourse, participants to the Comparative Q Methodology expressed to generally agree (across the five views) with statement 10 "Local public authorities do not adequately monitor service quality". Four out of the five views identified in Italy and China also agree with statement 12 "Water firms tend not to innovate and improve the quality of services over time". Among the initial and context conditions where water firms operate (statements 13-18 and statements 19-24), there are some strong differences between the Italian and Chinese discourses: in China, there is a stronger agreement across views that "The water sector contains too few firms to stimulate any form of competition" (statement 14) than in Italy, where there is instead a tendency across views to agree that "Water services provide an attractive opportunity for private investors" (statement 21) than in China. Both in China and Italy, instead, there is a controversy on whether "The attainment of profit bears negative effects on the quality of water services" (statement 15) and "Water firms are inherently inefficient because they are monopolists" (statement 18). In part, these results suggest that the two countries differ - apart from features of the institutional and political context - also in industrial and financial conditions. In part, they also suggest that, even in countries that exhibit such strong differences like Italy and China, similar issues arise about the efficiency and innovativeness of water firms, the effectiveness of monitoring activities, and on the effects of the profit motive on service quality.

Finally, the analysis also shows that in both countries there are similar controversies about the design options for water regulation. Beliefs that local water services should be provided "by business firms subjected to the pressure of market competition only" (statement 25) and "by cooperative firms" (statement 29) is generally opposed by all the views both in China and Italy. The design option to have local water services provided by "business firms subjected to the discretion of a regulatory agency" (statement 26) is also generally opposed in both 
This is the version of the article accepted for publication in Water Resources Management published by Springer: http://link.springer.com/journal/volumesAndlssues/11269

Accepted version downloaded from SOAS Research Online: http://eprints.soas.ac.uk/22868/

countries, setting aside the views of "fatalist privatizers" in Italy. Statements "Local water services should be provided by business firms subjected to terms and conditions of franchise contracts" (No. 27), "Local water services should be provided by mixed public-private ownership firms" (No. 28) and "Local water services should be provided by full public ownership firms" (No. 30), instead, spark controversies across views in both countries. These results suggest that, although Italy and China experience different trajectories in the development of water regulatory policies, at present none of them exhibits any sign of a 'hegemonic' discourse on how water services should be regulated - although some options, around which controversial views arise, are preferred than others.

The results from the analysis suggest that local public officers hold a very diverse and fragmented view on the regulation of water utilities both in Italy and in China. In both country contexts, the views on this topic cannot be easily mapped onto simplistic categories of "advocates" and "opponents" of public sector ownership or privatization of water service provision. Rather, local public officers hold nuanced understandings of water utilities regulation. These understandings include some positions about ownership structures and regulatory mechanisms, but they also address issues related to tariff principles, investment funding, organizational capabilities, and equity. In both countries, ideas on the regulation of water utilities seem unlikely to converge towards any unified or shared view. Most likely, conflictive policy perspectives will remain part of the political controversy that characterizes the water sector, despite of the apparent stability of water institutions.

\section{Conclusions}

This paper introduced the use of the Comparative Q Methodology to systematically map out and compare the beliefs of utilities regulators and managers. We tested this methodology using survey data from total 92 public officers from several cities in China and Italy. We found similarities as well as differences in the beliefs and ideas held by the participants to the 
This is the version of the article accepted for publication in Water Resources Management published by Springer: http://link.springer.com/journal/volumesAndlssues/11269

Accepted version downloaded from SOAS Research Online: http://eprints.soas.ac.uk/22868/

Comparative Q Methodology. In both Italy and China, respondents agreed on the importance of solidarity, protection of the most vulnerable users, and affordability of water services. They also largely agreed that public authorities do not adequately monitor service quality and that water firms tend not to innovate and improve service quality. In both countries, moreover, there are fragmented views on whether water services should be provided by business firms subjected to franchise contracts, mixed public-private ownership firms, or full public ownership firms. On the other hand, Italy and China exhibit divergent views on many respects. Funding infrastructure development by user charges is opposed in China, while it is a matter of controversy in Italy. Chinese respondents hold the pessimistic view that the water sector contains too few firms to stimulate any form of competition, while Italian respondents believe that water services provide an attractive opportunity for private investors.

These results may be understood in relation to the 'ongoing transition' that both countries experience, since a few decades, from a regime of widespread public ownership and control of water utilities to another regime where neo-liberal ideas (i.e., about the merits of privatization and business-like principles of water resources management) have entered the water policy domain. If ideas matter in the policy process, then such variety of perspectives on water utilities regulation suggests that water policy in these countries has not really settled in shared institutional arrangements yet. Rather, ideas that are present in the water policy discourse may contain the seeds of further adjustments to regulatory arrangements and managerial practices. The identification of such ideas helps anticipating future developments of the regulatory institutions and policies in both countries.

This study also includes some evidence about the method to access and analyze ideas in the water policy domain in comparative perspective. Ideas can play an important role in the water sector as in any policy domain: for example, beliefs about the desirability of alternative regulatory systems or opinions about the regulation of tariffs can have important repercussions on the search for efficiency improvements and innovation in technical and 
managerial tools. This study showed that Comparative Q Methodology provides a systematic way to identify viewpoints on the regulation of water utilities. When used in comparative perspective, the method can also help identifying similarities and differences in the ideas held across different country contexts. This contribution seems important, especially for the sake of examining the diffusion of policy ideas (e.g., neo-liberal principles in the regulation and management of water resources) across countries and regions in the world.

Our findings have several implications. First, the beliefs and ideas of public officers have implications for the design and enforcement of regulations. Second, the Comparative Q Methodology is a useful tool for systematically mapping out the beliefs of regulators and managers. Finally, systematically mapping out beliefs and ideas will help facilitate the development of an alternative regime of regulation such as negotiated rule making. Negotiated rule making is reputed to help attain a more efficient rule making process, more cost effective in terms of enforcement and compliance, more equitable in terms of balancing the interests of stakeholders and other benefits. Parties of negotiated rule making, however, need to approach the process with openness about each party's positions and preferences. This study showed that Q Methodology provides evidence of those issues that public officers in the water sector consider more salient and of their policy inclinations. Such information helps exploring how regulations should be drafted in order to deliver mutual advantages to parties involved. It can also help anticipating possible sources of conflict between parties and suggesting ways to prevent them. Comparative Q methodology offers a systematic way to build the foundations of this alternative regime of regulations.

This study has some limitations that should be acknowledged. The research design included the use of a Q sample whose sentences were theoretically derived, while in principle the concourse could be also obtained from evidence of the local political discourse. The same Q sample, therefore, might not fully capture the detailed and nuanced understanding of regulatory and managerial issues of public officers in Italy and China. The use of the same Q 
sample for the research conducted in both country contexts, however, is justified by the possibility to contrast and compare the views held by officers in the two countries. Another limitation is that the results of the analysis are silent with respect to the more fundamental issue of how exactly ideas matter in water utilities regulation. Additional research is needed, in this respect, to explain how ideas enter the policy discourse and might ultimately affect regulatory policy and managerial decisions.

\section{Acknowledgements}

This paper is jointly supported by the National Natural Science Foundation of China (71573151), the Major Program of the National Social Sciences Foundation of China (15ZDB164), National Key Research Program (2016YFC0401408), and Tsinghua University Initiative Scientific Research Program (2014z04083). The authors are grateful for the assistance from Ms. Jing-ning Kang. We are also grateful for the comments from anonymous reviewers and the editors. Any errors are the sole responsibility of the authors.

\section{References}

Araral, E. (2008). Public provision of urban water: Getting prices and governance right. Governance, 21, 527-549.

Araral, E. (2009). The failure of water utilities privatisation: Synthesis of evidence and implications. Policy \& Society, 27, 221-228.

Araral, E. (2013). Mechanism design and transaction cost approach to regulatory design in developing countries. Policy Science, December, 1-15. 
Araral, E., \& Wang, Y. (2013). Water Governance 2.0: a review and second generation research agenda. Water Resources Management, 27(11), 3945-3957.

Asquer, A. (2010). The regulatory reform of water infrastructure in Italy: Overall design and local variations. Water Policy, 12 (Suppl. S1), 66-83.

Asquer, A. (2011). The Regulation of Water Infrastructure in Italy: Evolution and Effects. In Infrastructure Regulation: What Works, Why, and How do We Know it? Lessons from Asia and Beyond; Jarvis, D., Ramesh, M., Xun, W., Eds.; World Scientific: Singapore.

Asquer, A. (2014). Understanding Subjectivities in the Regulation of Local Water Services: A Q-Methodology Study of Elected Public Officers in Italy. Water, 6(3), 670-693.

Ballance, A. \& Taylor, A (2005). Competition and Economic Regulation in Water: The Future of the European Water Industry; IWA Publishing: London.

Becker, G.S. (1983). A theory of competition among pressure groups for political influence. Q. J. Econ. 98, 371-400.

Béland, D. (2005). Ideas and social policy: an institutionalist perspective. Social Policy \& Administration, 39(1), 1-18.

Béland, D. (2009). Ideas, institutions, and policy change. Journal of European public policy, 16(5), 701-718. 
Blyth, M. (2001). The transformation of the Swedish model: Economic ideas, distributional conflict, and institutional change. World Politics, 54(1), 1-26.

Braehler, G.; Hackert, C. FlashQ 1.0, Q Sorting via the Internet. Available online: http://www.hackert.biz/flashq (accessed on 30 December 2013).

Brown, S. R. (1980). Political subjectivity: Applications of $Q$ methodology in political science. Yale University Press: New Haven, CT.

Campbell, J. L. (2002). Ideas, politics, and public policy. Annual review of sociology, 21-38.

Coglianese, C. (1997). Assessing consensus: The promise and performance of negotiated rulemaking. Duke Law Journal, 46(6), 1255-1349.

Dryzek, J.S. and Holmes, L. (2002). Post-Communist Democratization: Political Discourses across 13 Countries; Cambridge University Press: Cambridge.

Dryzek, J.S. and Berejikian, J. (1993). Reconstitutive democratic theory. Am. Polit. Sci. Rev. $87,48-60$.

Estache, A. \& Martimort, D. (1999). Politics, Transaction Costs, and the Design of Regulatory Institutions; World Bank Policy Research Working Paper No 2073, The World Bank: Washington.

Fischer, F., \& Gottweis, H. (2013). The argumentative turn in public policy revisited: twenty years later. Critical Policy Studies, 7(4), 425-433. 
Forester, J. "Critical Ethnography: On Field Work in an Habermasian Way," in Critical Management Studies, M. Alvesson, and H. Willmott (eds.), Sage Publications, London, 1992, pp. 46-65.

Friedland, R., \& Alford, R. R. (1991). Bringing society back in: Symbols, practices and institutional contradictions.

Goldstein, J., \& Keohane, R. O. (1993). Ideas and foreign policy: an analytical framework. Ideas and foreign policy. Beliefs, institutions, and political change, 3-30.

Gómez Ibáňez, J.A. (2003) Regulating Infrastructure: Monopoly, Contracts, and Discretion; Harvard University Press: Cambridge, MA.

Guerrini, A., Romano, G., \& Campedelli, B. (2011). Factors affecting the performance of water utility companies. International Journal of Public Sector Management, 24(6), 543-566.

Heilbroner, R. L., \& Milberg, W. S. (1995). The crisis of vision in modern economic thought. Cambridge University Press.

Hu, A. G., \& Wang, Y. H. (2000). China's Public Policy of Water Resources Allocation in Transition: Quasi-market, Political and Democratic Consultation. China Soft Science, 5, 001.

Jabko, N. (2006). Playing the market: a political strategy for uniting Europe, 1985-2005. Cornell University Press. 
This is the version of the article accepted for publication in Water Resources Management published by Springer: http://link.springer.com/journal/volumesAndlssues/11269

Accepted version downloaded from SOAS Research Online: http://eprints.soas.ac.uk/22868/

Jobert, B. (1989). The normative frameworks of public policy. Political studies, 37(3), 376386.

Jønch-Clausen, T., \& Fugl, J. (2001). Firming up the conceptual basis of integrated water resources management. International Journal of Water Resources Development, 17(4), 501510.

Kallis, G. \& Nijkamp, P. (2000). Evolution of EU Water Policy: A Critical Assessment and a Hopeful Perspective. Journal of Environmental Law Policy, 3, 301-355.

Katzenstein, P. J. (Ed.). (1996). The culture of national security: Norms and identity in world politics. Columbia University Press.

Kingdon, J. W. (1984). Agendas, alternatives, and public policies. Boston: Little, Brown.

Klijn, E. H. \& Koppenjan, J. F. M.(2004). Managing uncertainties in networks: a network approach to problem solving and decision making. Psychology Press.

Laffont, J.J. \& Tirole, J. (1993). A Theory of Incentives in Procurement and Regulation; MIT Press: Cambridge, MA.

Linton, J. (2010). What is water?: The history of a modern abstraction. UBC Press.

Lodge, M. \& Wegrich, K. (2012). Managing Regulation: Regulatory Analysis, Politics and Policy; Palgrave Macmillan: Basingstoke. 
This is the version of the article accepted for publication in Water Resources Management published by Springer: http://link.springer.com/journal/volumesAndlssues/11269

Accepted version downloaded from SOAS Research Online: http://eprints.soas.ac.uk/22868/

Marques, R. C., \& Berg, S. (2011). Risks, contracts, and private-sector participation in infrastructure. Journal of Construction Engineering and Management, 137(11), 925-932.

Marques, R. C., \& Simões, P. T. F. (2010). Regulation of water and wastewater services: An international comparison. IWA Publishing.

Massarutto, A. (2007). Water pricing and full cost recovery of water services: economic incentive or instrument of public finance?. Water Policy, 9(6), 591.

Massarutto, A., \& Ermano, P. (2013). Drowned in an inch of water: How poor regulation has weakened the Italian water reform. Utilities Policy, 24, 20-31.

Massarutto, A., Paccagnan, V., \& Linares, E. (2008). Private management and public finance in the Italian water industry: A marriage of convenience?. Water Resources Research, 44(12).

McMillan, J., \& Naughton, B. (1992). How to reform a planned economy: lessons from China. Oxford Review of Economic Policy, 130-143.

Majone, G. (1989). Evidence, argument, and persuasion in the policy process. Yale University Press.

Qian, Y., \& Weingast, B. R. (1996). China's transition to markets: market-preserving federalism, Chinese style. The Journal of Policy Reform, 1(2), 149-185.

Ogus, A.I. (1994). Regulation: Legal Form and Economic Theory; Clarendon Press: Oxford. 
This is the version of the article accepted for publication in Water Resources Management published by Springer: http://link.springer.com/journal/volumesAndlssues/11269

Accepted version downloaded from SOAS Research Online: http://eprints.soas.ac.uk/22868/

Parsons, C. (2002). Showing ideas as causes: the origins of the European Union. International organization, 56(01), 47-84.

Peltzman, S. (1989). Toward a more general theory of regulation. J. Law Econ. 19, 211-240.

Peters, G. (2011) Governance and political theory. Crit. Policy Stud. 5, 63-72.

Pigou, A.C. (1932). The Economics of Welfare; Macmillan: London.

Posner, R.A. (1974). Theories of Economic Regulation. Bell J. Econ. 2, 335-358.

Qiu, X., \& Li, H. L. (2008), China's environmental super ministry reform: background, challenges, and the future. Environmental Law Reporter, 39 ELR 10156, Environmental Law Institute, Washington, DC.

Rees, J.A. (1998). Regulation and private participation in the water and sanitation sector. Nat. Resour. Forum, 22, 95-105.

Richardson, V. (1996). The role of attitudes and beliefs in learning to teach. Handbook of research on teacher education, 2, 102-119.

Roe, E. (1994). Narrative policy analysis: Theory and practice. Duke University Press.

Romano, G., \& Guerrini, A. (2011). Measuring and comparing the efficiency of water utility companies: A data envelopment analysis approach. Utilities Policy, 19(3), 202-209. 
Romano, G., Guerrini, A., \& Vernizzi, S. (2013). Ownership, investment policies and funding choices of Italian water utilities: an empirical analysis. Water resources management, 27(9), 3409-3419.

Rothstein, B. (2005). Social traps and the problem of trust. Cambridge University Press.

Rouse, M. (2007). Institutional Governance and Regulation of Water Services; IWA Publishing: London.

Sabatier, P. A. (1988). An advocacy coalition framework of policy change and the role of policy-oriented learning therein. Policy sciences, 21(2-3), 129-168.

Sabatier, P. A., \& Jenkins-Smith, H. C. (1999). The advocacy coalition framework: An assessment. Theories of the policy process, 118, 188.

Schmidt, V. A. (2002). The futures of European capitalism. Oxford University Press.

Schmidt, V. A. (2008). Institutionalism. The Encyclopedia of Political Thought.

Schmidt, V. A. (2010). Taking ideas and discourse seriously: explaining change through discursive institutionalism as the fourth 'new institutionalism'. European political science review, 2(01), 1-25.

Schmidt, V. A. (2011). Speaking of change: why discourse is key to the dynamics of policy transformation. Critical policy studies, 5(2), 106-126. 
This is the version of the article accepted for publication in Water Resources Management published by Springer: http://link.springer.com/journal/volumesAndlssues/11269

Accepted version downloaded from SOAS Research Online: http://eprints.soas.ac.uk/22868/

Schmolck, P. PQMethod version 2.33. Available online: http://schmolck.userweb.mwn.de/qmethod/ (accessed on 30 December 2013).

Sigel, I. E. (1985). A conceptual analysis of beliefs. Parental belief systems: The psychological consequences for children, 1, 345-371.

Spulber, N. \& Sabbaghi (1994). A. Economics of Water Resources: From Regulation to Privatization; Kluwer Academic Publishing: Berlin.

Steelman, T. A., \& Maguire, L. A. (1999). Understanding participant perspectives: Qmethodology in national forest management. Journal of policy analysis and management, $18(3), 361-388$

Stephenson, W. (1953) The Study of Behavior: Q-technique and its Methodology; University of Chicago Press: Chicago, IL.

Stigler, G.J. (1971). The theory of economic regulation. Bell J. Econ. Manag. Sci. 2, 3-21.

Suchman, L. (1997). Centers of coordination: A case and some themes. In Discourse, Tools and Reasoning (pp. 41-62). Springer Berlin Heidelberg.

Thatcher, M. (1998). Institutions, regulation, and change: new regulatory agencies in the British privatised utilities. West European Politics, 21(1), 120-147.

Thatcher, M. (2002). Regulation after delegation: independent regulatory agencies in Europe. Journal of European Public Policy, 9(6), 954-972. 
Wang, Y. (2012). A simulation of water rights market with transaction costs. Agriculture Water Management, 103, pp.54-61

Wang, Y., \& Ching, L. (2013). Institutional legitimacy: an exegesis of normative incentives. International Journal of Water Resources Development, 29(4), 514-525.

Weaver, R. K., \& Rockman, B. A. (Eds.). (1993). Do institutions matter?: Government capabilities in the United States and abroad. Brookings Institution Press.

Winpenny, J. (1994). Managing Water as An Economic Resource; Routledge: London.

Zhang, D., Gersberg, R. M., Wilhelm, C., \& Voigt, M. (2009). Decentralized water management: rainwater harvesting and greywater reuse in an urban area of Beijing, China. Urban Water Journal, 6(5), 375-385. 
Table 1. The Q sample

\begin{tabular}{|c|c|c|c|c|}
\hline $\begin{array}{c}\text { Normative } \\
\text { stance }\end{array}$ & $\begin{array}{c}\text { Process } \\
\text { conditions }\end{array}$ & $\begin{array}{c}\text { Initial } \\
\text { conditions }\end{array}$ & $\begin{array}{c}\text { Context } \\
\text { conditions }\end{array}$ & $\begin{array}{c}\text { Design } \\
\text { principles }\end{array}$ \\
\hline $\begin{array}{l}\text { s1. Water } \\
\text { services should } \\
\text { be managed } \\
\text { according to } \\
\text { managerial } \\
\text { principles akin to } \\
\text { those of for... } \\
\text { profit firms. }\end{array}$ & $\begin{array}{l}\text { s7. Local public } \\
\text { authorities care } \\
\text { more about } \\
\text { protecting the } \\
\text { interests of water } \\
\text { firms than of the } \\
\text { users. }\end{array}$ & $\begin{array}{l}\text { s13. Local public } \\
\text { authorities do } \\
\text { not possess } \\
\text { adequate } \\
\text { knowledge, } \\
\text { competences, } \\
\text { and capabilities } \\
\text { to regulate the } \\
\text { conduct of water } \\
\text { firms. }\end{array}$ & $\begin{array}{l}\text { s19. Local public } \\
\text { authorities tend } \\
\text { to interfere in the } \\
\text { management of } \\
\text { water firms } \\
\text { rather than } \\
\text { supervising and } \\
\text { regulating their } \\
\text { conduct. }\end{array}$ & $\begin{array}{l}\text { s25. Local water } \\
\text { services should } \\
\text { be provided by } \\
\text { business firms } \\
\text { subjected to the } \\
\text { pressure of } \\
\text { market } \\
\text { competition only. }\end{array}$ \\
\hline
\end{tabular}

s2. Water

services should be managed according to principles of solidarity and of protection of the most vulnerable users. s8. In the tender

s14. The water

offer of franchise contracts, water firms tend to collude rather than compete. sector contains too few firms to stimulate any form of competition. s20. Water firms are not exposed to any serious threat of new entrants into the industry. s26. Local water

services should be provided by business firms subjected to the discretion of a regulatory agency.

$\begin{array}{ll} & \text { s9. If water } \\ & \text { services are } \\ \text { s3. Water tariffs } & \text { provided by } \\ \text { should cover full } & \text { franchisees, } \\ \text { cost, including a } & \text { water firms tend } \\ \text { fair return to } & \text { not to completely } \\ \text { capital invested. } & \begin{array}{l}\text { comply with } \\ \text { contractual } \\ \text { obligations. }\end{array}\end{array}$

s15. The attainment of profit bears negative effects on the quality of water services.

\section{s21. Water} services provide an attractive opportunity for private investors. s27. Local water services should be provided by business firms subjected to terms and conditions of franchise contracts.

s4. Water tariffs
should be kept
under the
control of
public
authorities to
ensure
affordability.

s10. Local public authorities do not adequately monitor service quality.

\section{s16. In the water} sector we lack reliable and comparable measures to assess the quality of services. s22. Users of water services are not able to compare the quality of the services with those provided by other water firms. s28. Local water services should be provided by mixed public-.private ownership firms. 
s5. Water infrastructure development should be primarily financed by users charges. s11. Renegotiation of water franchise contracts is highly demanding in terms of time and resources. s17. In the tender offer of franchise contracts, it is difficult to detail and enforce contractual terms and conditions. s23. The

administrative s29. Local water judicial system services should plays an important be provided by role in the cooperative regulation of water firms. firms.

\begin{tabular}{|c|c|c|c|c|}
\hline $\begin{array}{l}\text { s6. Water } \\
\text { infrastructure } \\
\text { development } \\
\text { should be } \\
\text { primarily } \\
\text { financed by }\end{array}$ & $\begin{array}{l}\text { s12. Water firms } \\
\text { tend not to } \\
\text { innovate and } \\
\text { improve the } \\
\text { quality of } \\
\text { services over }\end{array}$ & $\begin{array}{l}\text { s18. Water firms } \\
\text { are inherently } \\
\text { inefficient } \\
\text { because they are } \\
\text { monopolists. }\end{array}$ & $\begin{array}{l}\text { s24. Water firms } \\
\text { are provided } \\
\text { incentives to } \\
\text { operate efficiently. }\end{array}$ & $\begin{array}{l}\text { s30. Local water } \\
\text { services should } \\
\text { be provided by } \\
\text { full public } \\
\text { ownership firms. }\end{array}$ \\
\hline
\end{tabular}
public funds. time.

Table 2. Factor matrix with defining sorts (in bold): Italian context

\begin{tabular}{|c|c|c|c|c|c|c|}
\hline \multirow{2}{*}{$\begin{array}{c}\text { Respond } \\
\text { ent No. }\end{array}$} & \multirow{2}{*}{$\begin{array}{l}\text { Respond } \\
\text { ent ID }\end{array}$} & \multicolumn{5}{|l|}{ Factors } \\
\hline & & 1 & 2 & 3 & 4 & 5 \\
\hline 1 & CR1 & 0.3066 & -0.0665 & 0.5351 & 0.1606 & -0.1501 \\
\hline 2 & CL1 & 0.3117 & 0.3461 & 0.4480 & 0.1291 & -0.5067 \\
\hline 3 & CL2 & 0.0652 & 0.1304 & 0.6083 & 0.2813 & 0.1059 \\
\hline 4 & $\mathrm{C} 1$ & 0.2396 & -0.1540 & 0.6836 & 0.2407 & -0.1217 \\
\hline 5 & LF1 & 0.3565 & 0.6346 & 0.3367 & 0.2255 & 0.0480 \\
\hline 6 & CL3 & -0.0560 & 0.0601 & 0.1556 & 0.0163 & 0.1611 \\
\hline 7 & RT1 & 0.3671 & 0.7639 & 0.0070 & 0.0214 & 0.0446 \\
\hline 8 & LF2 & 0.6273 & 0.1554 & 0.3089 & -0.0863 & -0.0713 \\
\hline 9 & $\mathrm{C} 2$ & 0.0481 & 0.2961 & -0.0507 & 0.0444 & 0.9027 \\
\hline 10 & OT1 & 0.2153 & 0.0798 & 0.1132 & 0.6495 & 0.1094 \\
\hline 11 & LF3 & 0.7898 & 0.1444 & 0.1440 & -0.0324 & -0.1707 \\
\hline 12 & OT2 & 0.7237 & 0.1412 & 0.0435 & 0.0708 & -0.2788 \\
\hline 13 & CR1 & -0.2277 & 0.0515 & 0.0391 & 0.0688 & 0.4265 \\
\hline
\end{tabular}


Accepted version downloaded from SOAS Research Online: http://eprints.soas.ac.uk/22868/

\begin{tabular}{rrrrrrr}
14 & OT3 & $\mathbf{0 . 8 0 5 3}$ & 0.3106 & 0.1547 & 0.1055 & 0.0945 \\
15 & LF4 & -0.4282 & -0.0336 & 0.1534 & 0.3831 & 0.2295 \\
16 & OT4 & $\mathbf{0 . 8 0 3 9}$ & 0.1200 & 0.1104 & 0.1356 & 0.0284 \\
17 & CL4 & -0.1263 & -0.3549 & 0.2376 & 0.0078 & -0.3511 \\
18 & RT2 & 0.0516 & 0.4528 & -0.2500 & 0.1721 & 0.0091 \\
19 & CR2 & 0.2216 & $\mathbf{0 . 5 5 5 8}$ & 0.1123 & 0.0046 & 0.2062 \\
20 & LF5 & $\mathbf{0 . 8 0 6 5}$ & 0.0361 & 0.2702 & 0.1859 & -0.0893 \\
21 & C3 & 0.1647 & 0.1793 & $\mathbf{0 . 4 1 8 9}$ & -0.1098 & 0.0299 \\
22 & CR3 & 0.2585 & -0.1208 & -0.0058 & 0.3498 & -0.1032 \\
23 & CL5 & $\mathbf{0 . 7 2 2 9}$ & $\ldots .0 .1483$ & -0.1830 & 0.2606 & -0.0427 \\
24 & CL6 & 0.1023 & 0.1816 & 0.2093 & $\mathbf{0 . 4 4 3 4}$ & -0.0443 \\
\hline \multirow{2}{*}{$\%$ explained variance } & 21 & 9 & 9 & 5 & 7 \\
\hline
\end{tabular}

Table 3. Factor matrix with defining sorts (in bold): Chinese context

\begin{tabular}{|c|c|c|c|c|c|c|}
\hline \multirow{2}{*}{$\begin{array}{c}\text { Respond } \\
\text { ent No. }\end{array}$} & \multirow{2}{*}{$\begin{array}{l}\text { Respond } \\
\text { ent ID }\end{array}$} & \multicolumn{5}{|l|}{ Factors } \\
\hline & & 1 & 2 & 3 & 4 & 5 \\
\hline 1 & 0201 & -. 0.6315 & 0.4222 & 0.0051 & ..0.1947 & $\ldots 0.0482$ \\
\hline 2 & 0202 & 0.0575 & 0.6416 & 0.2505 & 0.0540 & 0.1553 \\
\hline 3 & 0203 & $\ldots 0.3478$ & 0.6530 & 0.2165 & 0.0795 & 0.0637 \\
\hline 4 & 0204 & ..0.0837 & 0.3034 & -.0.3846 & 0.1414 & 0.4382 \\
\hline 5 & 0303 & 0.1210 & 0.7557 & 0.0582 & -0.0436 & 0.0001 \\
\hline 6 & 0304 & 0.1210 & 0.7557 & 0.0582 & ...0.0436 & 0.0001 \\
\hline 7 & 0501 & 0.4010 & 0.7311 & 0.1910 & 0.0737 & 0.0735 \\
\hline 8 & 0502 & 0.5174 & 0.2727 & -.0.1281 & 0.2042 & $\ldots 0.1613$ \\
\hline 9 & 0503 & 0.3567 & 0.4993 & 0.0749 & 0.0147 & 0.2175 \\
\hline 10 & 0505 & 0.5221 & 0.2080 & 0.1968 & 0.0269 & 0.1894 \\
\hline
\end{tabular}




\begin{tabular}{|c|c|c|c|c|c|c|}
\hline 11 & 0506 & 0.8047 & 0.2681 & 0.0931 & $\ldots 0.0465$ & 0.1515 \\
\hline 12 & 0507 & 0.6264 & 0.1717 & 0.4180 & 0.0505 & $\ldots .0 .0221$ \\
\hline 13 & 0510 & 0.1508 & 0.3303 & 0.5713 & $\ldots 0.1568$ & $\ldots 0.1318$ \\
\hline 14 & 0511 & 0.1007 & 0.1840 & -0.3358 & $\ldots 0.1622$ & 0.1222 \\
\hline 15 & 0512 & 0.7858 & -.0.0966 & 0.2596 & $\cdots 0.0180$ & 0.0299 \\
\hline 16 & 0513 & 0.4047 & 0.7443 & 0.1092 & 0.0896 & 0.1487 \\
\hline 17 & 0514 & 0.3451 & 0.4385 &. .4726 & 0.4224 & -0.0554 \\
\hline 18 & 0515 & 0.3854 & 0.2678 & -0.1643 &. .0 .4649 & 0.3819 \\
\hline 19 & 0516 & -..0.0228 & 0.1024 & 0.2335 & 0.4018 & 0.4785 \\
\hline 20 & 0517 & 0.6765 & 0.4613 & -0.1332 & $\cdots 0.1516$ & 0.1343 \\
\hline 2 & 0518 & 0.0554 & 0.2837 & -0.0005 & 0.0296 & 0.2034 \\
\hline 22 & 0521 & 0.6831 & 0.3207 & -.0.3286 & $\ldots 0.0222$ & $\ldots 0.0743$ \\
\hline 23 & 0522 & 0.6661 & 0.1374 & 0.0468 & 0.0527 & -..1873 \\
\hline 2 & 0602 & 0.5000 & -.0.0081 & 0.4239 & 0.2121 & 0.1767 \\
\hline 25 & 0604 & 0.1169 & -..1930 & -.0.0358 & $\ldots 0.1223$ & 0.4814 \\
\hline 26 & 0606 & 0.6223 & 0.3067 & -0.1440 & 0.3569 & -.0.1436 \\
\hline 27 & 0611 & -.0.2931 & 0.2009 & -.0.0092 &. .0 .6174 & -.0.1362 \\
\hline 28 & 0612 & 0.0501 & 0.1209 & 0 - 5958 & ...0.1994 & $0 \cdots 5026$ \\
\hline 29 & 0613 & -0.2116 & 0.5977 & 0.3335 & 0.0136 & 0.2402 \\
\hline 30 & 0617 & 0.3828 & 0.4193 & 0.3707 & $\ldots 0.0732$ & 0.1343 \\
\hline 31 & 0618 & 0.0183 & 0.0915 & 0.1062 & 0.1641 & 0.5659 \\
\hline 32 & 0619 & 0.1940 & 0.1944 & -.0.0592 & $\ldots 0.1212$ & 0.5545 \\
\hline 33 & 0622 & 0.5917 & 0.2157 & 0.0635 & ...1929 & -.0.0622 \\
\hline 34 & 0623 & 0.0815 & -..0.0707 & 0.6549 & 0.0584 & 0.1210 \\
\hline 35 & 0624 & 0.2860 & 0.4124 & 0.2170 & $\ldots 0.0115$ & 0.3410 \\
\hline 36 & 0627 & 0.3333 & 0.0739 & -.0.0303 & 0.0333 & 0.6167 \\
\hline 37 & 0631 & $\ldots 0.0543$ & 0.3504 & -.0.1870 & $\ldots 0.4061$ & 0.5587 \\
\hline 38 & 0633 & 0.2234 & 0.2126 & 0.2981 & 0.3555 & 0.2384 \\
\hline 39 & 0634 & 0.1146 & 0.2879 & 0.2040 & 0.2729 & ...4336 \\
\hline 4 & 0635 & 0.0492 & 0.1204 & 0.6548 & 0.1519 & 0.0939 \\
\hline
\end{tabular}


Accepted version downloaded from SOAS Research Online: http://eprints.soas.ac.uk/22868/

\begin{tabular}{|c|c|c|c|c|c|c|}
\hline 41 & 0637 & 0.1039 & -0.0280 & -0.0122 &. .0 .5210 & 0.1974 \\
\hline 42 & 0640 & 0.2359 & 0.5828 & 0.1220 & 0.2113 & ...0.0976 \\
\hline 43 & 0642 & 0.6062 & 0.1940 & 0.2493 & -.0 .0419 &. .0 .1026 \\
\hline 44 & 0643 & 0.6808 & 0.2934 & 0.0662 & 0.1666 & 0.0852 \\
\hline 45 & 0645 & 0.0357 & -..0799 & 0.4049 & 0.0722 & 0.4938 \\
\hline 46 & 0648 & 0.5059 & $\ldots 0.2640$ & 0.0865 & 0.1104 & 0.0025 \\
\hline 47 & 0649 & 0.3865 & 0.3346 & -..0.0931 & -0.2376 & 0.2278 \\
\hline 48 & 0651 & 0.1714 & 0.4480 & -.0.0482 & ...1910 & 0.4533 \\
\hline 49 & 0652 & 0.6609 & 0.0095 & 0.0604 & 0.1883 & 0.1832 \\
\hline 50 & 0654 & 0.3537 & 0.1214 & 0.2462 & ...0.0828 & 0.3579 \\
\hline 51 & 0901 & 0.3967 & 0.1641 & 0.3242 & 0.2361 & 0.3267 \\
\hline 52 & 0903 & -.0.1635 & 0.3038 & 0.2321 & 0.0425 & 0.7323 \\
\hline 53 & 0908 & 0.6826 & 0.1095 & 0.1297 & 0.0344 & 0.2235 \\
\hline 54 & 0911 & -0.1750 & 0.1304 & 0.0971 & -0.1028 & 0.5636 \\
\hline 55 & 0915 & 0.2958 & 0.5263 & 0.0494 & 0.2682 & 0.1622 \\
\hline 56 & 0916 & 0.5462 & 0.2465 & 0.4334 & 0.2831 & 0.3494 \\
\hline 57 & 0918 & 0.3356 & 0.2525 & -.0.2157 & 0.0355 & 0.2331 \\
\hline 58 & 1001 & 0.2362 & 0.5269 & 0.0440 & 0.5545 & 0.1815 \\
\hline 59 & 1002 & 0.5913 & 0.1403 & -..1302 & 0.1703 & 0.2169 \\
\hline 60 & 1005 & 0.0908 & 0.1787 & 0.1154 & ...5515 & 0.4690 \\
\hline 61 & 1010 & $\ldots .2078$ & 0.5675 & -.0.0407 & $\cdots 0.044$ & $\ldots 0.0731$ \\
\hline 62 & 1012 & 0.6047 & -.0 .0161 & 0.1214 & -0.2924 & 0.1978 \\
\hline 63 & 1014 & 0.3226 & 0.4979 & 0.0080 & -0.0628 & 0.3477 \\
\hline 64 & 1016 & 0.6042 & -..0.0697 & 0.1694 & -.0 .0840 & $\ldots 0.1540$ \\
\hline 65 & 1018 & 0.2843 & -0.1105 & 0.3826 & -.0 .0137 & 0.0963 \\
\hline 66 & 1019 & 0.0115 & 0.3598 & 0.1099 & -..0.1011 & 0.1728 \\
\hline 67 & 1023 & $\ldots .0350$ & 0.2758 & 0.4472 & 0.1335 & $\ldots 0.2257$ \\
\hline 68 & 1028 & 0.3955 & 0.2403 & 0.5685 & 0.5417 & $\ldots 0.0252$ \\
\hline
\end{tabular}


Table 4. Factor $Q$ sort values for each statement: Italian context

\section{Statements}

Factors

$\begin{array}{lllll}1 & 2 & 3 & 4 & 5\end{array}$

1 Water services should be managed according to business principles akin to those of for--profit firms.

$\begin{array}{lllll}-3 & -3 & 2 & -5 & -2\end{array}$

2 Water services should be managed according to principles of solidarity and of protection of the most vulnerable users.

3 Water tariffs should cover full cost, including a fair return to capital invested.

$\begin{array}{lllll}-4 & 1 & 4 & -2 & 0\end{array}$

4 Water tariffs should be kept under the control of public authorities to ensure affordability.

5 Water infrastructure development should be primarily financed by users charges.

$\begin{array}{lllll}-1 & -4 & 3 & 3 & -1\end{array}$

6 Water infrastructure development should be primarily financed by public funds.

7 Local public authorities care more about protecting the interests of water firms than of the users.

8 In the tender offer of franchise contracts, water firms tend to collude rather than compete.

9 If water services are provided by franchisees, water firms tend not to completely comply with contractual obligations.

10 Local public authorities do not adequately monitor service quality.

11 Renegotiation of water franchise contracts is highly demanding in terms of time and resources.

12 Water firms tend not to innovate and improve the quality of services over time.

13 Local public authorities do not possess adequate knowledge, competences, and capabilities to regulate the conduct of water firms.

14 The water sector contains too few firms to stimulate any form of competition.

15 The attainment of profit bears negative effects on the quality of water services. 
This is the version of the article accepted for publication in Water Resources Management published by Springer:

16 In the water sector we lack reliable and comparable measures to assess the quality of services.

17 In the tender offer of franchise contracts, it is difficult to detail and enforce contractual terms and conditions.

18 Water firms are inherently inefficient because they are monopolists. $\begin{array}{ccccc}1 & -1 & -1 & -4 & 0\end{array}$

19 Local public authorities tend to interfere in the management of water firms rather than supervising and regulating their conduct.

20 Water firms are not exposed to any serious threat of new entrants into the industry.

21 Water services provide an attractive opportunity for private investors.

$\begin{array}{lllll}3 & 3 & 1 & 0 & 4\end{array}$

22 Users of water services are not able to compare the quality of the services with those provided by other water firms.

$\begin{array}{lllll}2 & 0 & 3 & 1 & 2\end{array}$

23 The administrative judicial system plays an important role in the regulation of water firms.

24 Water firms are provided incentives to operate efficiently.

25 Local water services should be provided by business firms subjected to the pressure of market competition only.

26 Local water services should be provided by business firms subjected to the discretion of a regulatory agency.

27 Local water services should be provided by business firms subjected to terms and conditions of franchise contracts.

28 Local water services should be provided by mixed public-.-private ownership firms.

29 Local water services should be provided by cooperative firms.

30 Local water services should be provided by full public ownership firms.

Table 5. Factor Q sort values for each statement: Chinese context

\section{Statements}

Factors 
1 Water services should be managed according to business principles akin to those of for--profit firms.

2 Water services should be managed according to principles of solidarity and of protection of the most vulnerable users.

$\begin{array}{lllll}1 & 3 & 3 & 2 & 2\end{array}$

3 Water tariffs should cover full cost, including a fair return to capital invested.

$\begin{array}{lllll}\cdots 2 & 4 & 4 & 1 & 5\end{array}$

4 Water tariffs should be kept under the control of public authorities to ensure affordability.

$\begin{array}{lllll}2 & 4 & 1 & 2 & 3\end{array}$

5 Water infrastructure development should be primarily financed by users charges.

6 Water infrastructure development should be primarily financed by public funds.

7 Local public authorities care more about protecting the interests of water firms than of the users.

8 In the tender offer of franchise contracts, water firms tend to collude rather than compete.

9 If water services are provided by franchisees, water firms tend not to completely comply with contractual obligations.

10 Local public authorities do not adequately monitor service quality.

$\begin{array}{lllll}3 & 0 & 2 & 4 & 1\end{array}$

11 Renegotiation of water franchise contracts is highly demanding in terms of time and resources.

$\begin{array}{lllll}0 & 1 & \cdots & 0 & 1\end{array}$

12 Water firms tend not to innovate and improve the quality of services over time.

13 Local public authorities do not possess adequate knowledge, competences, and capabilities to regulate the conduct of water firms.

14 The water sector contains too few firms to stimulate any form of competition.

15 The attainment of profit bears negative effects on the quality of water services.

16 In the water sector we lack reliable and comparable measures to assess the quality of services.

17 In the tender offer of franchise contracts, it is difficult to detail and enforce contractual terms and conditions.

18 Water firms are inherently inefficient because they are monopolists. 
19 Local public authorities tend to interfere in the management of water firms rather than supervising and regulating their conduct.

20 Water firms are not exposed to any serious threat of new entrants into the industry.

21 Water services provide an attractive opportunity for private investors.

22 Users of water services are not able to compare the quality of the services with those provided by other water firms.

$\begin{array}{lllll}2 & 2 & 0 & \cdots 3 & 3\end{array}$

23 The administrative judicial system plays an important role in the regulation of water firms.

24 Water firms are provided incentives to operate efficiently. $\begin{array}{lllll}\cdots 4 & 0 & \cdots 3 & 1 & \cdots 1\end{array}$

25 Local water services should be provided by business firms subjected to the pressure of market competition only.

26 Local water services should be provided by business firms subjected to the discretion of a regulatory agency.

27 Local water services should be provided by business firms subjected to terms and conditions of franchise contracts.

28 Local water services should be provided by mixed public-.-private ownership firms.

29 Local water services should be provided by cooperative firms.

30 Local water services should be provided by full public ownership firms.

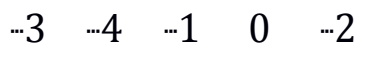

$\begin{array}{lllll}\cdots 2 & 3 & \cdots 3 & 3 & \cdots\end{array}$

Table 6. Correlations between factor scores: Italian context

\begin{tabular}{cccccc}
\hline & $\mathbf{1}$ & $\mathbf{2}$ & $\mathbf{3}$ & $\mathbf{4}$ & $\mathbf{5}$ \\
\hline 1 & 1 & 0.4999 & 0.3761 & 0.3301 & -0.0263 \\
2 & 0.4999 & 1 & 0.2324 & 0.2891 & 0.2852 \\
3 & 0.3761 & 0.2324 & 1 & 0.3693 & 0.0118 \\
4 & 0.3301 & 0.2891 & 0.3693 & 1 & 0.1430 \\
5 & -0.0263 & 0.2852 & 0.0118 & 0.1430 & 1 \\
\hline
\end{tabular}


Table 7. Correlations between factor scores: Chinese context

\begin{tabular}{cccccc}
\hline & $\mathbf{1}$ & $\mathbf{2}$ & $\mathbf{3}$ & $\mathbf{4}$ & $\mathbf{5}$ \\
\hline 1 & 1 & 0.3910 & 0.2371 & 0.1316 & 0.1758 \\
2 & 0.3910 & 1 & 0.2085 & 0.0562 & 0.3386 \\
3 & 0.2371 & 0.2085 & 1 & 0.1543 & 0.1721 \\
4 & 0.1316 & 0.0562 & 0.1543 & 1 & $\cdots 0.1698$ \\
5 & 0.1758 & 0.3386 & 0.1721 & -0.1698 & 1 \\
\hline
\end{tabular}

Table 8. Defining statements for each factor (Z-scores $>1$ or $<-1)$ : Italian context

Factor No. 1 Rank Zwscore

Agrees especially with the following statements

s3

$0 \quad$ Local water services should be provided by full public ownership firms. 5

s2 Water services should be managed according to principles of solidarity $4 \quad \begin{aligned} & 1.578\end{aligned}$

s2 and of protection of the most vulnerable users. s4 Water tariffs should be kept under the control of public authorities to
ensure affordability.

s1 The attainment of profit bears negative effects on the quality of water $3 \quad \begin{aligned} & 1.235 \\ & 5\end{aligned}$

5 services.

s2

1 Water services provide an attractive opportunity for private investors. $3 \quad 1.026$

Disagrees especially

with the following

statements

\begin{tabular}{lll}
\hline s2 & Local water services should be provided by business firms subjected to & \\
6 & the discretion of a regulatory agency. & -1.341
\end{tabular}


s2 Local water services should be provided by business firms subjected to

7 terms and conditions of franchise contracts.

Water tariffs should cover full cost, including a fair return to capital

s2 Local water services should be provided by business firms subjected to

5 the pressure of market competition only.

\section{Factor No. 2}

Agrees especially with the following statements

s1 The attainment of profit bears negative effects on the quality of water

5 services.

s1 Local public authorities tend to interfere in the management of water

9 firms rather than supervising and regulating their conduct.

s1 Local public authorities do not possess adequate knowledge,

3 competences, and capabilities to regulate the conduct of water firms.

Disagrees especially with the following statements

s2 Local water services should be provided by business firms subjected to

5 the pressure of market competition only.

Water infrastructure development should be primarily financed by

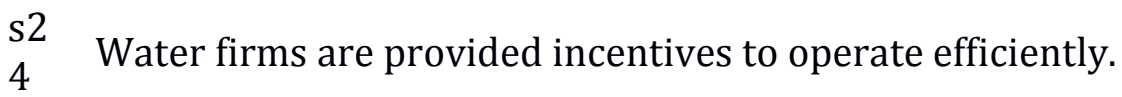

Local water services should be provided by cooperative firms.

$-5 \quad-1.894$

\section{Factor No. 3}

Agrees especially with the following statements
s2
Water services should be managed according to principles of solidarity and of protection of the most vulnerable users. 
Disagrees especially with the following statements

\begin{tabular}{llll}
\hline s2 & Local water services should be provided by business firms subjected to & & -1.653 \\
7 & terms and conditions of franchise contracts. & \\
& $\begin{array}{l}\text { Local public authorities care more about protecting the interests of } \\
\text { s7 }\end{array}$ & -4 & -1.735 \\
& $\begin{array}{l}\text { water firms than of the users. } \\
\text { s2 }\end{array}$ & $\begin{array}{l}\text { Local water services should be provided by business firms subjected to } \\
5\end{array}$ & 5 \\
\hline
\end{tabular}

Factor No. 4

Agrees especially with the following statements

\begin{tabular}{|c|c|c|c|}
\hline s2 & $\begin{array}{l}\text { Water services should be managed according to principles of solidarity } \\
\text { and of protection of the most vulnerable users. }\end{array}$ & 5 & 2.287 \\
\hline s4 & $\begin{array}{l}\text { Water tariffs should be kept under the control of public authorities to } \\
\text { ensure affordability. }\end{array}$ & 4 & 1.679 \\
\hline \multicolumn{4}{|l|}{ s1 } \\
\hline 0 & Local public authorities do not adequately monitor service quality. & 4 & 1.378 \\
\hline s5 & $\begin{array}{l}\text { Water infrastructure development should be primarily financed by } \\
\text { users charges. }\end{array}$ & 3 & 1.071 \\
\hline $\begin{array}{l}s 1 \\
6\end{array}$ & $\begin{array}{l}\text { In the water sector we lack reliable and comparable measures to assess } \\
\text { the quality of services. }\end{array}$ & 3 & 1.071 \\
\hline
\end{tabular}

Disagrees especially with the following statements

\begin{tabular}{llll}
\hline s9 & $\begin{array}{l}\text { If water services are provided by franchisees, water firms tend not to } \\
\text { completely comply with contractual obligations. }\end{array}$ & -3 & -1.523 \\
s2 & & -4 & -1.528 \\
9 & Local water services should be provided by cooperative firms. & \\
s1 & & -4 & -1.679 \\
8 & Water firms are inherently inefficient because they are monopolists. & & -1.986 \\
s1 & $\begin{array}{l}\text { Water services should be managed according to business principles } \\
\text { akin to those of for--profit firms. }\end{array}$ & -5 & -4 \\
\hline
\end{tabular}

\section{Factor No. 5}

Agrees especially with the following statements

s2 Local water services should be provided by mixed public-..private

8 ownership firms.

s2

1 Water services provide an attractive opportunity for private investors.

s2 Local water services should be provided by business firms subjected to

6 the discretion of a regulatory agency. 
s2 Water firms are not exposed to any serious threat of new entrants into

0 the industry.

s1 Local public authorities do not possess adequate knowledge,

3 competences, and capabilities to regulate the conduct of water firms.

Local public authorities care more about protecting the interests of water firms than of the users.

Disagrees especially with the following statements

\begin{tabular}{llll}
\hline s2 & Water firms are provided incentives to operate efficiently. & -3 & -1.162 \\
4 & W & Local water services should be provided by business firms subjected to & \\
s2 & -3 & -1.201 \\
5 & the pressure of market competition only. & & \\
s3 & & -3 & -1.201 \\
0 & Local water services should be provided by full public ownership firms. & -3 \\
s1 & Renegotiation of water franchise contracts is highly demanding in & -4 & -1.366 \\
1 & terms of time and resources. & & \\
s2 & & -4 & -1.601 \\
9 & Local water services should be provided by cooperative firms. & & \\
s2 & The administrative judicial system plays an important role in the & -5 & -1.923 \\
3 & regulation of water firms. & & \\
\hline
\end{tabular}

Table 9. Defining statements for each factor (Z-scores $>1$ or $<-1)$ : Chinese context

\section{$\mathbf{Z}$}

Factor No. 1

Rank

Agrees especially with the following statements

s6

Water infrastructure development should be primarily financed by public funds.

The water sector contains too few firms to stimulate any form of competition. 
The attainment of profit bears negative effects on the quality of water services.

s10 Local public authorities do not adequately monitor service quality.

Disagrees especially with the following statements

s5 Water infrastructure development should be primarily financed by users charges.

Water services should be managed according to business principles

s1 akin to those of

for-"-profit firms.

s24 Water firms are provided incentives to operate efficiently.

Local water services should be provided by business firms subjected to the discretion of a regulatory agency.

\section{Factor No. 2}

Agrees especially with the following statements

\begin{tabular}{|c|c|c|c|}
\hline s6 & $\begin{array}{l}\text { Water infrastructure development should be primarily financed by } \\
\text { public funds. }\end{array}$ & 5 & 1.971 \\
\hline s4 & $\begin{array}{l}\text { Water tariffs should be kept under the control of public authorities to } \\
\text { ensure affordability. }\end{array}$ & 4 & 1.681 \\
\hline s3 & $\begin{array}{l}\text { Water tariffs should cover full cost, including a fair return to capital } \\
\text { invested. }\end{array}$ & 4 & 1.645 \\
\hline s2 & $\begin{array}{l}\text { Water services should be managed according to principles of solidarity } \\
\text { and of protection of the most vulnerable users. }\end{array}$ & 3 & 1.307 \\
\hline s30 & Local water services should be provided by full public ownership firms. & 3 & 1.069 \\
\hline \multicolumn{4}{|c|}{ Disagrees especially with the following statements } \\
\hline s5 & $\begin{array}{l}\text { Water infrastructure development should be primarily financed by } \\
\text { users charges. }\end{array}$ & $\ldots 5$ & $\cdots 2.329$ \\
\hline s25 & $\begin{array}{l}\text { Local water services should be provided by business firms subjected to } \\
\text { the pressure of market competition only. }\end{array}$ &. .4 & $\cdots 1.114$ \\
\hline s29 & Local water services should be provided by cooperative firms. &.-4 & -1.047 \\
\hline s16 & $\begin{array}{l}\text { In the water sector we lack reliable and comparable measures to assess } \\
\text { the quality of services. }\end{array}$ &. .3 & $\ldots 1.007$ \\
\hline
\end{tabular}

\section{Factor No. 3}

Agrees especially with the following statements 


\begin{tabular}{|c|c|c|c|}
\hline s1 & $\begin{array}{l}\text { Water services should be managed according to business principles } \\
\text { akin to those of } \\
\text { for--profit firms. }\end{array}$ & 5 & 2.350 \\
\hline s3 & $\begin{array}{l}\text { Water tariffs should cover full cost, including a fair return to capital } \\
\text { invested. }\end{array}$ & 4 & 1.701 \\
\hline s14 & $\begin{array}{l}\text { The water sector contains too few firms to stimulate any form of } \\
\text { competition. }\end{array}$ & 4 & 1.257 \\
\hline s16 & $\begin{array}{l}\text { In the water sector we lack reliable and comparable measures to assess } \\
\text { the quality of services. }\end{array}$ & 3 & 1.129 \\
\hline s2 & $\begin{array}{l}\text { Water services should be managed according to principles of solidarity } \\
\text { and of protection of the most vulnerable users. }\end{array}$ & 3 & 1.092 \\
\hline \multicolumn{4}{|c|}{ Disagrees especially with the following statements } \\
\hline s23 & $\begin{array}{l}\text { The administrative judicial system plays an important role in the } \\
\text { regulation of water firms. }\end{array}$ & $\cdots 5$ & $\cdots 1.878$ \\
\hline s28 & $\begin{array}{l}\text { Local water services should be provided by mixed public-..private } \\
\text { ownership firms. }\end{array}$ & $\cdots 4$ & $\cdots 1.736$ \\
\hline s26 & $\begin{array}{l}\text { Local water services should be provided by business firms subjected to } \\
\text { the discretion of a regulatory agency. }\end{array}$ & $\cdots 4$ & -1.624 \\
\hline s30 & Local water services should be provided by full public ownership firms. & -3 & -1.140 \\
\hline s24 & Water firms are provided incentives to operate efficiently. & $\ldots 3$ & -1.106 \\
\hline
\end{tabular}

\section{Factor No. 4}

Agrees especially with the following statements

\begin{tabular}{llrr}
\hline s15 & $\begin{array}{l}\text { The attainment of profit bears negative effects on the quality of water } \\
\text { services. }\end{array}$ & 5 & 1.901 \\
s13 & $\begin{array}{l}\text { Local public authorities do not possess adequate knowledge, } \\
\text { competences, and capabilities to regulate the conduct of water firms. }\end{array}$ & 4 & 1.476 \\
s10 & $\begin{array}{l}\text { Local public authorities do not adequately monitor service quality. } \\
\text { s30 }\end{array}$ & 4 & 1.462 \\
Local water services should be provided by full public ownership firms. & 3 & 1.278 \\
s12 & $\begin{array}{l}\text { Water firms tend not to innovate and improve the quality of services } \\
\text { over time. }\end{array}$ & 3 & 1.107 \\
s28 & $\begin{array}{l}\text { Local water services should be provided by mixed public-.private } \\
\text { ownership firms. }\end{array}$ & 3 & 1.072 \\
\hline
\end{tabular}

Disagrees especially with the following statements 
Local water services should be provided by business firms subjected to the discretion of a regulatory agency.

Local water services should be provided by business firms subjected to

terms and conditions of franchise contracts.

s18 Water firms are inherently inefficient because they are monopolists.

\section{Factor No. 5}

Agrees especially with the following statements

\begin{tabular}{|c|c|c|c|}
\hline s3 & $\begin{array}{l}\text { Water tariffs should cover full cost, including a fair return to capital } \\
\text { invested. }\end{array}$ & 5 & 1.882 \\
\hline s16 & $\begin{array}{l}\text { In the water sector we lack reliable and comparable measures to assess } \\
\text { the quality of services. }\end{array}$ & 4 & 1.571 \\
\hline s14 & $\begin{array}{l}\text { The water sector contains too few firms to stimulate any form of } \\
\text { competition. }\end{array}$ & 4 & 1.502 \\
\hline s22 & $\begin{array}{l}\text { Users of water services are not able to compare the quality of the } \\
\text { services with those provided by other water firms. }\end{array}$ & 3 & 1.460 \\
\hline s4 & $\begin{array}{l}\text { Water tariffs should be kept under the control of public authorities to } \\
\text { ensure affordability. }\end{array}$ & 3 & 1.184 \\
\hline s20 & $\begin{array}{l}\text { Water firms are not exposed to any serious threat of new entrants into } \\
\text { the industry. }\end{array}$ & 3 & 1.154 \\
\hline
\end{tabular}

Disagrees especially with the following statements

\begin{tabular}{|c|c|c|c|}
\hline s7 & $\begin{array}{l}\text { Local public authorities care more about protecting the interests of } \\
\text { water firms than of the users. }\end{array}$ & -.5 & -.2.062 \\
\hline s6 & $\begin{array}{l}\text { Water infrastructure development should be primarily financed by } \\
\text { public funds. }\end{array}$ &. .4 & -1.448 \\
\hline s5 & $\begin{array}{l}\text { Water infrastructure development should be primarily financed by } \\
\text { users charges. }\end{array}$ &. .4 & 1.397 \\
\hline
\end{tabular}

s30 Local water services should be provided by full public ownership firms. $\quad \cdots 3 \quad-\cdots 1.283$ 